\title{
Kepercayaan Masyarakat Menabung pada Bank Umum Syariah
}

\author{
Dianing Ratna Wijayani \\ Universitas Muria Kudus \\ dianing.ratna.wijayani@gmail.com
}

\begin{abstract}
The main basis of banking activity is trust, in both the collection of funds and distribution of funds. People will save their money in the bank if it is based on trust. In this function, it will be built trust by both the depositors and the bank staff, and this trust will continue to debtors. This trust is important to establish because in these circumstances all parties want to get benefits from some aspects. In other words, the higher the public trust, the higher the third party funds which will get in the bank. The purpose of this research is to analyze the influence of Sharia Supervisory Board, profitability and cost of promotions toward public trust in Islamic Banks. The populations of this study are all commercial Syaria banks in period of 2011-2013, with a purposive sampling technique and obtained sample of 11 banks. The type of data used in this research is secondary data, similar documentation of the financial statements of Islamic banks in 2011-2013. Results of analysis using multiple regression are: The sharia supervisory board has influence toward public trust in saving money in Islamic banks, this indicates that the sharia supervisory board will presume that the professionalism and intensity of supervision of Islamic banks are higher, so the trust level of saving money in Islamic banks are higher, Profitability has no effect on public trust in saving money in Islamic banks, and they do not pay much attention to profit, this indicates that people who save money in Islamic banks pay more attention to the security of the liberation from the shackles of usury. Promotion cost has effect on public trust in Islamic banks, this indicates that people who save money in Islamic banks pay less attention to profits and is considered usury by Muslims, so bank benefits are not paid much attention to profits, and they pay more attention to the security in order to prevent usury.
\end{abstract}

Keywords: Sharia Supervisory Board, Profitability, Profit Sharing and Trust

\begin{abstract}
Abstrak
Dasar utama kegiatan perbankan adalah kepercayaan (trust), baik dalam penghimpun dana maupun penyaluran dana. Masyarakat akan mau menyimpan dana dananya di bank apabila dilandasi kepercayaan. Dalam fungsi ini akan di bangun kepercayaan baik dari pihak penyimpan dana maupun dari pihak bank dan kepercayaan ini akan terus berlanjut kepada pihak debitor. Kepercayaan ini penting dibangun karena dalam keadaan ini semua pihak ingin merasa diuntungkan baik dari segi penyimpangan dana, penampung dana maupun penerima penyaluran dana tersebut. Dengan kata lain, semakin tinggi kepercayaan masyarakat maka semakin tinggi pula dana pihak ketiga (DPK) yang akan masuk pada bank tersebut.Tujuan dalam penelitian ini adalah untuk menganalisa pengaruh Dewan Pengawas Syariah (DPS), profitabilitas dan biaya promosi terhadap kepercayaan masyarakat menabung di Bank Umum Syariah. Populasi dalam penelitian ini adalah seluruh bank umum Syariah periode 2011-2013, dengan teknik pengambilan sampel purposive sampling diperoleh sampel sebanyak 11 bank. Jenis data yang dipergunakan adalah data sekunder, serupa dokumentasi laporan keuangan
\end{abstract}


bank syariah tahun 2011-2013. Hasil analisis dengan menggunakan regresi berganda adalah: Dewan pengawas syariah berpengaruh terhadap kepercayaan masyarakat menabung di bank syariah, hal ini mengindikasikan bahwa adanya dewan pengawas syariah akan memberikan asumsi profesionalisme dan intensitas pengawasan bank syariah semakin tinggi, sehingga tingkat kepercayaan menabung di bank syariah tersebut semakin tinggi. Profitabilitas tidak berpengaruh terhadap kepercayaan masyarakat menabung di bank syariah tidak terlalu memperhatikan laba, hal ini mengindikasikan bahwa masyarakat yang menabung di bank syariah lebih memperhatikan keamanan dari sisi terbebasnya dari jeratan ribawi. Biaya promosi berpengaruh terhadap kepercayaan masyarakat menabung di bank syariah, hal ini mengindikasikan bahwa masyarakat yang menabung di bank syariah kurang memperhatikan laba dan dianggap riba oleh umat islam, sehingga keuntungan bank tidak terlalu memperhatikan laba, mereka lebih memperhatikan keamanan dari sisi terbebasnya jeratan ribawi

Kata Kunci : Dewan Pengawas Syariah, Profitabilitas, Bagi Hasil dan Kepercayaan

\section{PENDAHULUAN}

Undang-Undang No. 10 Tahun 1998 tentang Perbankan, mendefinisikan bank sebagai badan usaha yang menghimpun dana dari masyarakat dalam bentuk simpanan dan menyalurkannya kepada masyarakat, dalam bentuk kredit dan atau bentukbentuk lainnya dalam rangka meningkatkan taraf hidup rakyat banyak. Pasal 5 Undang-Undang No.10 Tahun 1998, tentang Perbankan, terdapat dua jenis bank, yaitu Bank Umum dan Bank Perkreditan Rakyat. Kedua jenis bank tersebut dalam menjalankan kegiatan usahanya diklasifikasikan menjadi dua, yaitu bank Konvensional dan bank dengan prinsip Syariah.

Bank syariah merupakan fenomena baru dalam dunia ekonomi modern. Kemunculannya seiring dengan upaya yang dilakukan oleh para pakar Islam untuk mendukung ekonomi Islam yang diyakini akan dapat mengganti dan memperbaiki sistem ekonomi konvensional yang berbasis bunga. Prinsip syariah adalah aturan perjanjian berdasarkan hukum Islam antara pihak bank dan pihak lain untuk penyimpanan dana dan pembiayaan kegiatan usaha berdasarkan syariat Islam.

Bank syariah adalah bank yang beroperasi dengan tidak mengandalkan pada bunga. Bank syariah merupakan lembaga keuangan perbankan yang operasional dan produknya dikembangkan berlandaskan pada Al-Qur'an dan Hadist Nabi saw. Dengan kata lain Bank Umum Syariah adalah bank yang melakukan kegiatan usaha atau beroperasi berdasarkan prinsip syariah dan tidak mengandalkan pada bunga dalam memberikan pembiayaan dan jasa-jasa lainnya dalam lalu lintas pembayaran (Muhammad, 2005: 10).

Permintaan masyarakat di Indonesia dalam jasa perbankan syariah yang semakin meningkat mendorong para pelaku bisnis perbankan untuk membuka bank yang didasarkan pada prinsip syariah. Adanya perbankan syariah di Indonesia dipelopori oleh berdirinya Bank Muamalat Indonesia yang diprakarsai oleh Majelis Ulama Indonesia (MUI) dengan tujuan mengakomodir berbagai aspirasi dan pendapat di masyarakat terutama masyarakat Islam yang banyak berpendapat bahwa bunga bank itu haram karena termasuk riba. 
Menurut Arifin (2000: 10), meskipun sebagian orang Islam berpendapat bahwa bunga bank itu bukan riba tetapi faedah, karena bunga yang diberikan atau diambil oleh bank berjumlah kecil jadi tidak akan saling dirugikan atau didzolimi, tetapi tetap saja bagi umat Islam berdirinya bank-bank syariah adalah sebuah kemajuan besar. Sistem perbankan syariah dijalankan atas dasar filosofi relijiusitas, landasan keadilan, dan orientasi falah. Filosofi relijiusitas melahirkan basis ekonomi dengan atribut pelarangan riba atau bunga (Q.S. Al-Baqarah: 275, 278-279; An-Nisa', 29; Ali-Imran:130).

Mengikuti jejak Bank Muamalat Indonesia, tidak sedikit bank konvensional yang juga membuka pelayanan jasa perbankan syariah. Sebut saja Bank Syariah Mandiri, Bank BNI Syariah, Bank Mega Syariah, Bank Syariah Bukopin, BRI Syariah, CIMB Niaga Syariah dan lain-lain. Di samping bank-bank besar berskala nasional, usaha keuangan syariah di tingkat mikro juga tumbuh pesat di berbagai daerah. Saat ini terdapat 11 bank umum syariah di Indonesia, 23 unit usaha syariah, dan 151 bank perkreditan rakyat syariah (Indriastuti, 2011: 12).

Pada awalnya perbankan syariah mematok pangsa pasar (market share) sebanyak 5 persen dari total pemilik rekening di Indonesia. Namun akibat krisis, BI menilai market share perbankan syariah hanya mencapai 4,8 persen hingga akhir tahun. Market share perbankan syariah di Indonesia masih terbilang masih kecil. Dari waktu ke waktu pergeserannya masih harus terus dilakukan.

Dasar utama kegiatan perbankan adalah kepercayaan (trust), baik dalam penghimpun dana maupun penyaluran dana. Masyarakat akan mau menyimpan dana dananya di bank apabila dilandasi kepercayaan. Dalam fungsi ini akan di bangun kepercayaan baik dari pihak penyimpan dana maupun dari pihak bank dan kepercayaan ini akan terus berlanjut kepada pihak debitor. Kepercayaan ini penting dibangun karena dalam keadaan ini semua pihak ingin merasa diuntungkan baik dari segi penyimpanan dana, penampung dana maupun penerima penyaluran dana tersebut. Dengan kata lain, semakin tinggi kepercayaan masyarakat maka semakin tinggi pula dana pihak ketiga (DPK) yang akan masuk pada bank tersebut.

Kinerja perbankan syariah pada tahun 2013 menunjukkan kinerja yang baik. Penghimpunan Dana Pihak Ketiga (DPK) dari Bank Umum Syariah dan Unit Usaha Syariah (UUS) pada tahun 2013 mencapai Rp. 156,96 triliun, meningkat sebesar Rp. 9,45 triliun (6.41\%) dibanding tahun 2012 atau sebesar Rp. 37,32 riliun (33,8\%), dibandingkan tahun sebelumnya. Peningkatan komponen DPK tertinggi terjadi pada deposito mudharabah yang meningkat sebesar Rp. 11,69 triliun menjadi Rp. 96,42 triliun, diikuti tabungan wadi'ah dan mudharabah sebesar Rp. 1,4 triliun menjadi Rp 46,4 triliun (Statistik Perbankan Syariah 2013). Hal tersebut menunjukan meningkatnya kepercayaan masyarakat terhadap bank syariah. Banyak fakta yang dapat mempengaruhi kepercayaan masyarakat terhadap bank syariah, diantaranya adalah:

1. Adanya Dewan Pengawas Syariah (DPS)

2. Profitabilitas

3. Adanya promosi

Fungsi pengawasan terpadu berlandaskan syariah adalah salah satu ciri yang membedakan antara bank Islam dengan bank konvensional. Hal ini terwujud dalam bentuk keharusan adanya Dewan Pengawas Syariah (DPS) pada bank Islam. Eksistensi DPS dapat menampik anggapan menyangkal yang berpendapat bahwa tidak ada 
bedanya antara bank syariah dan bank konvensional. DPS dapat mengawasi segala aktivitas bank agar selalu sesuai dengan prinsip-prinsip syariah. Dengan kata lain, DPS bertanggung jawab atas produk dan jasa yang ditawarkan kepada masyarakat agar sesuai dengan prinsip syariah: investasi atau proyek yang ditangani oleh bank harus juga sesuai dengan prinsip syariah, dan tentu saja bank itu sendiri harus di kelola sesuai dengan prinsip syariah.

Tugas DPS adalah meneliti dan membuat rekomendasi produk baru dari bank yang diawasinya. Dengan demikian, DPS bertindak sebagai penyaring pertama sebelum suatu produk diteliti kembali dan difatwakan oleh DSN (Antonio, 2001: 15). Adanya DPS dapat meyakinkan masyarakat bahwa bank Syariah beroperasi sesuai dengan hukum Islam.

Persaingan antar bank syariah yang semakin ketat, secara langsung ataupun tidak langsung, akan berpengaruh terhadap pencapaian profitabilitas bank syariah. Kemampuan bank syariah dalam menghasilkan profit menjadi indikator penting keberlanjutan entitas bisnis. Selain itu, kemampuan menghasilkan profit menjadi indikator penting untuk mengukur kemampuan bersaing bank syariah dalam jangka panjang. Nasabah atau masyarakat dalam memilih bank untuk berinvestasi atau menabung (menyimpan dana) tentunya memiliki dasar pertimbangan yang logis. Diantaranya, infomasi yang masyarakat atau nasabah butuhkan yaitu: tingkat profitabilitas dan likuditas bank tersebut.

Profitabilitas sangat dibutuhkan dalam membangun daya elektromagnetis suatu bank dalam menarik hati masyarakat atau nasabah untuk menyimpan. Setiap masyarakat atau nasabah yang ingin berinvestasi selalu mengutamakan dua hal, yaitu profit yang tinggi dan keamanan investasi yang terjamin. Informasi tentang tingkat keuntungan suatu bank bisa diperoleh dengan melihat laporan keuangan periodeperiode sebelumnya. Unsur tersebut dapat membangun keinginan masyarakat atau nasabah untuk percaya pada bank tersebut yang nantinya di jadikan pilihan untuk berinvestasi karena bank tersebut berkonsentrasi pada profitabilitas yang tinggi maka dapat menyebabkan nilai return on asset (ROA) yang tinggi pula. Jika demikian hal ini dapat menimbulkan peluang kepercayaan yang lebih bagi bank untuk masyarakat atau nasabah yang akan menabung atau berinvestasi di bank tersebut. Gerrard dan Cunningham (1997: 16) melakukan penelitian di Singapura dengan hasil menunjukkan, bahwa motivasi religiusitas dan profitabilitas secara bersama-sama menjadi dasar sikap masyarakat muslim terhadap bank Islam. Penelitian Haron dan Planisek (1974: 40) menyebut bahwa alasan profitabilitas merupakan alasan utama memanfaatkan bank syariah.

Hubungan dengan DPS agar bank tersebut semakin dipercaya oleh masyarakat dengan mekanisme syariah-nya, sedangkan profitabilitas dapat membuat kelangsungan nilai ROA tersebut semakin tinggi yang dapat membuat masyarakat semakin percaya terhadap bank syariah untuk berinvestasi, karena rasa aman, tertib, dan menyetujui dalam syariat Islam. Tidak cukup dengan DPS dan profitabilitas saja, bank syariah harus dapat berkomunikasi langsung dengan masyarakat dengan melalui promosi.

Promosi merupakan salah satu variabel dalam bauran pemasaran (marketing mix) yang sangat penting oleh perusahan untuk memasarkan produknya. Kegiatan 
promosi bukan saja berfungsi sebagai alat komunikasi antara bank dengan masyarakat, melainkan juga sebagai alat untuk mempengaruhi masyarakat dalam berinvestasi di bank syariah. Hal ini dilakukan dengan menggunakan alat-alat promosi yang sesuai dengan kebutuhan bank. Penyediaan biaya promosi dapat dihubungkan dengan pendapatan penjualan perusahaan. Dapat dikatakan pula bahwa dalam teorinya apabila biaya promosi besar atau dinaikkan dari sebelumnya maka penjualan dalam hal ini adalah dana pihak ketiga pun ikut mengalami kenaikan, tetapi dalam faktanya kenaikan jumlah biaya promosi seringkali tidak diimbangi dengan kenaikan dana pihak ketiga.

Volume dana pihak ketiga (DPK) dapat dijadikan indikasi tingkat kepercayaan masyarakat pada bank yang bersangkutan. Semakin tinggi volume dana pihak ketiga mengindikasikan masyarakat semakin percaya kepada bank yang bersangkutan. Sebaliknya bila volume dana pihak ketiga semakin turun maka mengindikasikan masyarakat semakin menurun kepercayaannya kepada bank tersebut (Taswan, 2010: 35).

Peneliti terdahulu, Wulandari (2013: 40) hanya menggunakan empat variabel sebagai variabel prediktor internal dan eksternal yang mempengaruhi total dana pihak ketiga (DPK). Hasilnya menunjukan bahwa hanya satu variabel yang berpengaruh sigifikan terhadap DPK BUS. Masih terdapat variabel prediktor internal dan eksternal lainnya yang mempengaruhi DPK BUS di Indonesia. Oleh karena itu, menyarankan untuk peneliti selanjutnya menggunakan faktor internal berupa variabel profitabilitas, serta faktor eksternal berupa lembaga. Pemilihan variabel tersebut didasarkan pada hasil penelitian ini dan perkembangan ekonomi yang kian maju dimana lembaga perbankan terus bersaing meningkatkan DPK nya. Menurut Masliana (2011: 60) fenomena yang terjadi saat ini dalam praktik pengawasan syariah di bank-bank syariah di Indonesia adalah peran vital DPS belum berjalan secara optimal, bahkan sangat jauh dari peran yang semestinya mereka jalankan. Banyak dari mereka tidak berperan sama sekali dalam mengawasi operasional perbankan syariah.

\section{TINJAUAN PUSTAKA}

\section{Pengaruh DPS terhadap Kepercayaan Masyarakat Menabung di Bank Umum Syariah}

DPS mempunyai peran penting terhadap implementasi bank syariah yang sesuai dengan ketentuan syariah. Semakin banyak anggota dewan yang melakukan pengawasan semestinya akan semakin sempurna dalam implementasi ketentuan syariah. Hal ini tidak hanya dapat menguntungkan bank tersebut tetapi dapat membuat masyarakat semakin percaya dan minat menabung di bank syariah tersebut semakin tinggi. Namun demikian profesionalisme DPS sangatlah diperlukan.

Menurut Bernardi (1994: 35) profesionalisme Dewan Pengawas Syariah (DPS) adalah tingkat penguasaan dan pelaksanaan terhadap knowledge, skill, dan character. Semakin banyak anggota DPS (asumsi profesionalisme) maka intensitas melakukan pengawasan semakin tinggi.

Menurut Bonner dan Lewis (1990: 25) perilaku profesional diperlukan bagi semua profesi, agar profesi yang telah menjadi pilihannya mendapat kepercayaan dari masyarakat.

Menurut hasil penelitian, Bank Indonesia juga memberikan rekomendasi kebi- 
jakan bahwa kualitas pemahaman prinsip-prinsip syari'ah dalam transaksi perbankan sangat vital untuk meningkatkan keyakinan masyarakat akan profesionalisme DPS sebagai kunci untuk menjamin bahwa kegiatan operasional bank sesuai dengan prinsip syari'ah.

Maka hipotesis pertama dalam penelitian ini adalah:

H1: Dewan Pengawas Syariah berpengaruh terhadap kepercayaan masyarakat menabung di bank umum syariah.

\section{Pengaruh Profitabilitas terhadap Kepercayaan Masyarakat Menabung di Bank Umum Syariah}

Profitabilitas berpengaruh terhadap masyarakat menabung di bank karena semakin tinggi profitabilitas, semakin tinggi pula nilai ROA maka secara langsung DPK akan meningkat pula yang mana akan menarik masyarakat atau nasabah untuk menabung atau berinvestasi.

Menurut Kurniawati (2012: 45) profitabilitas berpengaruh positif terhadap minat masyarakat berinvestasi atau menabung. Bagi masyarakat untuk melihat profitabilitas bank dapat dilihat dari besarnya bagi hasil yang diterima.

Hasil penelitian Wahyuni (2016: 275) tingkat keuntungan hasil bagi berpengaruh positif dan signifikan terhadap keputusan nasabah menggunakan perbankan syariah. Sehingga apabila tingkat bagi hasil yang di berikan bank kepada nasabah tersebut semakin tinggi maka akan tinggi pula keputusan nasabah atau masyarakat untuk menabung.

Maka hipotesis kedua dari penelitian ini adalah:

H2: Profitabilitas berpengaruh terhadap kepercayaan masyarakat menabung di bank umum syariah.

\section{Pengaruh Biaya Promosi terhadap Kepercayaan Masyarakat Menabung di Bank Umum Syariah.}

Semakin baik kegiatan promosi yang dilakukan maka masyarakat akan semakin mengerti atau memahami tentang bank syariah dan produk-produknya serta berminat menabung atau berinvestasi di bank tersebut. Untuk mengetahui kesungguhan bank dalam melakukan promosi dapat dilihat dari besarnya biaya promosi yang dilakukan. Jika semakin tinggi biaya promosi yang dikeluarkan, kegiatan promosi akan semakin meluas. Maka dapat berakibat DPK akan meningkat.

Menurut penelitian oleh Sandaika (2004: 86) yang melakukan penelitian mengenai pengaruh total biaya promosi terhadap penghimpunan dana pihak ketiga pada Bank Jabar kantor pusat. Karena hal ini akan memberikan pengetahuan dan edukasi yang lebih luas kepada masyarakat akan produk-produk yang ditawarkan oleh perbankan syariah, serta hasil penelitian yang telah dilakukan oleh Hamonangan dan Nirmalawati (2008: 54) yang melihat efektivitas promosi terhadap peningkatan Dana Pihak Ketiga pada Bank Rakyat Indonesia dengan menggunakan pendekatan Error Correction Model. Serta hasil penelitian yang dilakukan Siringoringo (2006: 54) dengan melakukan metode analisis Error Correction Model berdasarkan data panel, dimana dilakukan observasi pengaruh biaya promosi bank terhadap penghimpunan tabungan dan deposito terhadap sepuluh bank terbaik berdasarkan aset di tahun 2005 .

Maka hipotesis ketiga dari penelitian ini adalah: 
H3: Biaya Promosi berpengaruh terhadap Kepercayaan masyarakat menabung di bank umum syariah.

\section{Kerangka Penelitian}

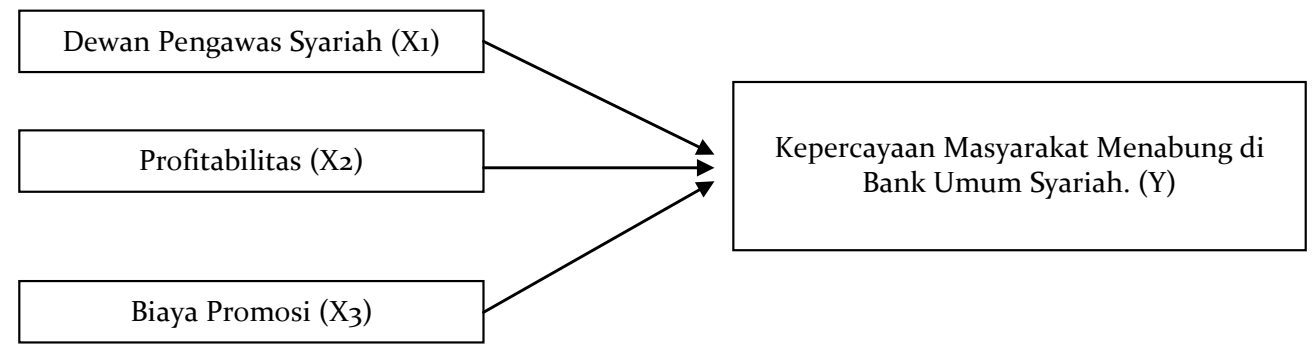

Gambar 1. Kerangka Penelitian

\section{METODE PENELITIAN}

Populasi yang diambil dalam penelitian ini adalah seluruh data tentang dana DPK, banyaknya anggota DPS, profitabilitas, dan biaya promosi pada seluruh bank umum syariah periode 2011-2013. Teknik pengambilan sampel yang digunakan adalah purposive sampling dengan tujuan untuk mendapatkan sampel yang sesuai dengan tujuan penelitian. Metode purposive sampling merupakan metode pengambilan sampel yang didasakan pada beberapa pertimbangan atau kriteria tertentu. Kriteria data yang akan menjadi sampel dalam penelitian ini adalah data-data yang lengkap pada periode 2011-2013 pada 11 Bank umum syariah : (1. PT. Bank Syariah Mandiri, 2. PT. Bank Muamalat Indonesia, 3. PT. Bank BNI Syariah, 4. PT. Bank BRI Syariah, 5. Bank Mega Syariah, 6. PT. Bank Jabar dan Banten, 7. PT. Bank Panin Syariah, 8. PT. Bank Bukopin Syariah, 9. PT. Bank Victoria Syariah, 10. PT. BCA Syariah, 11. PT. MayBank Indonesia Syariah).

\section{Definisi Operasional dan Pengukuran}

Variabel penelitian yang terdapat dalam penelitian ini terdiri dari dua jenis variabel yaitu:

1. Variabel dependen (Variabel Y) merupakan variabel yang nilainya dipengaruhi oleh variabel independen. Variabel dependen dalam penelitian ini yaitu Kepercayaan masyarakat yang diukur dengan Dana Pihak Ketiga (DPK).

2. Variabel independen (Variabel X) merupakan variabel yang menjadi sebab terjadinya atau terpengaruhinya variabel dependen. Variabel independen dalam penelitian ini adalah DPS, Profitabilitas, dan Promosi.

Definisi masing-masing variabel adalah sebagai berikut:

1. Kepercayaan Masyarakat (Y)

Kepercayaan masyarakat adalah kepercayaan untuk menyimpan dana ke bank syariah, yang diukur dengan banyaknya dana pihak ketiga (DPK) yang masuk pada bank syariah yang terdiri dari tabungan, deposito, dan giro.

2. Dewan Pengawas Syariah (X1)

DPS adalah dewan yang bertugas untuk mengawasi jalannya lembaga keuangan syariah agar sesuai dengan ketentuan-ketentuan syariah, yang diukur dari banya- 
knya anggota DPS.

3. Profitabilitas (X2)

Profitabilitas adalah kemampuan bank dalam menghasilkan keuntungan, yang diukur dari rasio return on asset (ROA).

4. Promosi (X3)

Promosi adalah kegiatan untuk mempengaruhi dan menjelaskan atau menyampaikan kepada masyarakat tentang produk-produk di bank syariah, yang diukur dari biaya promosi (rupiah).

\section{Metode Analisis Data}

Dalam upaya menjawab permasalahan dalam penelitian ini maka digunakan analisis regresi linear berganda (Multiple Regression). Analisis regresi pada dasarnya adalah studi mengenai ketergantungan variabel dependen (terikat) dengan satu atau lebih variabel independen (bebas), dengan tujuan untuk mengestimasi dan memprediksi rata-rata populasi atau nilai-nilai variabel dependen berdasarkan nilai variabel independen yang diketahui (Ghozali, 2005: 123).

Persamaan dalam regresi ini adalah untuk mengetahui Dewan Pengawas Syariah (X1), Profitabilitas (X2), Biaya Promosi (X3) terhadap variabel Kepercayaan Masyarakat (Y).

Rumus persamaan regresinya adalah sebagai berikut:

$\mathrm{Y}=\mathrm{a}+b_{1} X_{1}+b_{2} X_{2}+b_{3} X_{3}+\mathrm{e}$

Keterangan:

$\mathrm{Y}=$ Kepercayaan Masyarakat

$\mathrm{a}=$ Konstanta

$\mathrm{X} 1$ = Dewan Pengawas Syariah (DPS)

$\mathrm{X} 2=$ Profitabilitas

$\mathrm{X} 3=$ Promosi

b1 $=$ Koefesien regresi Dewan Pengawas Syariah

b2 = Koefisien regresi Profitabilitas

b3 = Koefisien regresi Promosi

e $\quad=$ Error atau variabel lain yang mempengaruhi diluar persamaan regresi tersebut

\section{HASIL PENELITIAN}

\section{Pengujian Hipotesis}

Hasil pengujian hipotesis dilakukan dengan menggunakan regresi berganda diperoleh hasil sebagai berikut :

1. Hipotesis 1

Dewan pengawas syariah berpengaruh terhadap kepercayaan masyarakat, hasil ini dibuktikan dengan nilai t hitung dewan pengawas syariah (tabel. 1) adalah sebesar 2,229 > t tabel 2,045 dan nilai signifikasi 0,034<0,05. Dengan demikian dapat disimpulkan bahwa $\mathrm{H}_{\mathrm{o}}$ ditolak dan Ha yang menyatakan dewan pengawas syariah berpengaruh positif terhadap kepercayaan masyarakat menabung di bank syariah diterima. 
2. Hipotesis 2

Profitabilitas tidak berpengaruh terhadap kepercayaan masyarakat, hasil ini dibuktikan dengan nilai t hitung profitabilitas (tabel. 1) adalah sebesar 0,255 < t tabel 2,045 dan nilai signifikasi 0,801 >0,05. Dengan demikian dapat disimpulkan bahwa $\mathrm{H}_{\mathrm{o}}$ diterima dan $\mathrm{Ha}$ yang menyatakan profitabilitas berpengaruh terhadap kepercayaan masyarakat menabung di bank syariah ditolak.

3. Hipotesis 3

Biaya promosi berpengaruh terhadap kepercayaan masyarakat, hasil ini dibuktikan dengan nilai t hitung biaya promosi (tabel. 1) adalah sebesar 14,640 $>$ t tabel 2,045 dan nilai signifikasi $0,000<0,05$. Dengan demikian dapat disimpulkan bahwa $\mathrm{H}_{\mathrm{o}}$ ditolak dan $\mathrm{Ha}$ yang menyatakan biaya promosi berpengaruh positif terhadap kepercayaan masyarakat menabung di bank syariah diterima.

Tabel. 1 Uji t

\begin{tabular}{lrrrrr}
\hline \multirow{2}{*}{ Keterangan } & \multicolumn{3}{c}{ Unstandardized } & \multirow{2}{*}{ t hitung } & Sig \\
\cline { 2 - 5 } Constant & -1489878 & Std. Error & & \\
DPS & 664838 & 2982667,2 & $-1,979$ & 0,057 \\
ROA & & 28514,318 & 111943,9 & 2,229 & 0,034 \\
B. Promosi & & 76,890 & 5,252 & 14,640 & 0,000 \\
R $^{2}$ & 0,884 & & & & \\
F & 73,552 & Sig. o,ooo & & & \\
\hline
\end{tabular}

\section{Pengujian Model Regresi (Uji F)}

Pengujian ini dilakukan untuk mengetahui apakah dewan pengawas syariah, profitabilitas dan biaya promosi secara bersama-sama berpengaruh signifikan terhadap kepercayaan masyarakat menabung di bank syariah. Nilai $F_{\text {hitung }}(73,552)$, dan signifikasi 0,000<0,05, (tabel. 1) dengan demikian dewan pengawas syariah, profitabilitas dan biaya promosi secara bersama-sama berpengaruh signifikan terhadap kepercayaan masyarakat menabung di bank syariah. Dengan demikian model regresi dalam penelitian ini adalah baik untuk penelitian.

\section{Koefisien Determinasi}

Persentase variabel dependen (kepercayaan masyarakat menabung di bank syariah) dapat dijelaskan oleh variabel independen (dewan pengawas syariah, profitabilitas dan biaya promosi) dalam model penelitian ditunjukkan oleh besarnya koefisien determinasi. Koefisien determinasi ini menunjukan seberapa besar pengaruh variabel bebas terhadap variabel dependen yang dinyatakan dalam persen (\%).

Berdasarkan tabel.1 dapat diketahui bahwa nilai koefisien determinasi yang ditunjukkan dengan $R$ square adalah sebesar 0,884 persen, artinya (dewan pengawas syariah, profitabilitas dan biaya promosi) dapat menjalaskan kepercayaan masyarakat menabung di bank syariah sebesar $88,40 \%$ sedangkan sisanya diterangkan oleh faktor yang lain dalam penelitian, seperti $C A R$, Sertifikat Wadiah Bank Indonesia, dan lain-lain. 


\section{PEMBAHASAN}

\section{Pengaruh Dewan Pengawas Syariah Terhadap Kepercayaan Masyarakat Menabung di Bank Syariah}

Dewan pengawas syariah berpengaruh positif terhadap kepercayaan masyarakat menabung di bank syariah, artinya apabila dewan pengawas syariah semakin banyak, maka kepercayaan masyarakat menabung di bank syariah akan semakin meningkat. Hal ini mengindikasikan bahwa dewan pengawas syariah mempunyai peranan penting terhadap implementasi bank syariah yang sesuai dengan ketentuan syariah, dimana dengan adanya dewan pengawas syariah, maka tingkat penguasaan dan pelaksanaan knowledge, skill dan character semakin tinggi, sehingga asumsi profesionalisme dan intensitas pengawasan bank syariah semakin tinggi. Kondisi tersebut yang membuat masyarakat percaya dengan keberadaan bank syariah tersebut. Hasil ini mendukung penelitian Bernardi (1994:68) yang menyatakan semakin banyak dewan pengawas syariah, maka pengawasan terhadap bank syariah semakin meningkat, sehingga masayrakat akan semakin percaya dan minat menabung di bank syariah tersebut semakin tinggi.

\section{Pengaruh Profitabilitas (ROA) Terhadap Kepercayaan Masyarakat Menabung di Bank Syariah}

Profitabilitas tidak berpengaruh terhadap kepercayaan masyarakat menabung di bank syariah, artinya besar kecilnya profitabilitas yang di miliki oleh bank syariah tidak mempengaruhi kepercayaan masyarakat menabung di bank syariah. Hal ini mengindikasikan bahwa masyarakat yang menabung di bank syariah tidak terlalu memperhatikan laba, mereka lebih memperhatikan keamanan dari sisi terbebasnya dari jeratan ribawi. Hasil ini mendukung penelitian Kurniawati (2012: 69), yang menyatakan profitabilitas tidak berpengaruh signifikan terhadap kepercayaan masyarakat menabung di bank syariah.

\section{Pengaruh Biaya Promosi Terhadap Kepercayaan Masyarakat Menabung di Bank Syariah}

Biaya promosi berpengaruh positif terhadap kepercayaan masyarakat menabung di bank syariah, apabila biaya promosi semakin meningkat, maka kepercayaan masyarakat menabung di bank syariah akan semakin meningkat pula. Hal ini mengindikasikan bahwa semakin baik kegiatan promosi yang dilakukan, maka masyarakat semakin mengerti atau memahami tentang bank syariah dan produk-produknya serta berminat menabung atau berinvestasi di bank tersebut. Promosi dilakukan dengan memberikan pengetahuan dan edukasi yang lebih luas kepada masyarakat akan produk-produk yang di tawarkan oleh perbankan syariah, sehingga masyarakat akan lebih tertarik untuk menggunakan jasa bank tersebut. Hasil ini mendukung penelitian Sandaika (2004:76) yang menyatakan bahwa biaya promosi berpengaruh terhadap penghimpunan dana oleh bank.

\section{PENUTUP}

Berdasarkan hasil penelitian ini dapat disimpulkan; pertama, bahwa dewan pengawas syariah berpengaruh terhadap kepercayaan masyarakat menabung di bank syariah, hal ini mengindikasikan bahwa adanya dewan pengawas syariah akan mem- 
berikan asumsi profesionalisme dan intensitas pengawasan bank syariah semakin tinggi, sehingga tingkat kepercayaan menabung di bank syariah tersebut semakin tinggi. Kedua, ditinjau dari tingkat profitabilitas, bahwa tidak ada pengaruh antara profibilitas tersebut terhadap kepercayaan masyarakat menabung di bank syariah. $\mathrm{Ke}$ tiga, dilihat dari segi biaya promosi, hal tersebut berpengaruh terhadap kepercayaan masyarakat menabung di bank syariah. Oleh karena itu, masyarakat yang menabung di bank syariah lebih memperhatikan kenyamanan dari sisi spiritual dikarenakan terbebas dari jeratan riba.

\section{DAFTAR PUSTAKA}

Al Arief, Nur Rianto. (2010). Dasar-Dasar Pemasaran Bank Syariah. Bandung: Alfabeta.

Antonio, Muhammad, Syafii. (2001). Bank Syariah dari Teori ke Praktik. Jakarta: Gema Insani Press.

Arifin, Zainal. (2000). Memahami Bank Syariah: Lingkup, Peluang, Tantangan dan Prospek. Jakarta: Alvabet.

Bernardi, R.A. (1994). "Fraud Detection: The Effect of Client Integrity and Competence and Auditor Cognitive Style. Auditing: A Journal of Theory and Practice, 13 (supplement):68-84

Bonner, S. \& B. Lewis. (1990). Dimensions of Auditors Expertise. Journal of Accounting Research. Vol. 28 Supplement: 1-20.

Data Statistik Perbankan Syariah. (2013). Direktorat Perbankan Syariah Bank Indonesia.

Gerrard, Philip \& Barton Cunningham J. (1997). Islamic Banking: A Study in Singapore. International Journal of Bank Marketing. 15(6), 204-216

Ghozali, Imam. (2005). Aplikasi Analisis Multivariat dengan program SPSS. Semarang: Badan Penerbit Universitas Diponegoro.

Hamonangan, Jefri \& T, Dyah Nirmalawati. (2008). Efektifitas Promosi Terhadap Peningkatan Dana Pihak Ketiga Pada PT. Bank Rakyat Indonesia. National Conference On Management Research.

Haron \& Planisek. (1974). The Effects of Conventional Interest Rates and Rate of Profit on Funds Deposited with Islamic Banking Sistem in Malaysia. International Journal of Islamic Financial Services, 1, 4.

Indriastuti, Maya. (2011). Analisis Kualitas Auditor Dan Corporate Governance Terhadap Manajemen Laba. Eksistansi, 4(2).

Keputusan Dewan Pimpinan MUI tentang susunan pengurus DSN-MUI, No: Kep-98/MUI/ III/2001) Tentang Pedoman Rumah Tangga Dewan Syariah Nasional.

Kurniawati, Eris Tri. (2012). Analisis Pengaruh Profitabilitas Sistem Bagi Hasil dan Kualitas Layanan Bank terhadap Minat Nasabah Berinvestasi (Studi Kasus Pada Bank Muammalat Cabang Malang). Jurnal Humanity. 7(2).

Masliana. (2011). Peran Dewan Pengawas Syariah (DPS) dalam Pengawasan Pelaksanaan Kontrak di Bank Syariah (Studi pasa Bank BRI Syariah).Skripsi. Jakarta: UIN Syarif Hidayatullah.

Muhammad. (2001). Audit Dan Pengawasan Syariah Pada Bank Syariah Catatan Pengalaman. Yogyakarta: UII Press. p. 18.

Muhammad. (2005). Manajeman Bank Syariah. Yogyakarta: UPP AMP YKPN.

Sandaika, Fatra. (2004). Pengaruh Total Biaya Promosi Terhadap Penghimpunan Dana Pihak Ketiga Pada PT Bank Jabar Kantor Pusat. Bandung: Politeknik Negeri Bandung. Tugas Akhir

Siringoringo. (2006). Analisis Pengaruh Promosi Bank Terhadap Penghimpunan Tabungan dan Deposito (Studi Kasus Sepuluh Bank Terbaik Berdasarkan Aset 2005). Skipsi. Bo- 
gor: Fakultas Ekonomi dan Manajemen Institut Pertanian Bogor.

Supranto, J. (1994). Statistik Teori dan Aplikasinya. Jilid 1. Jakarta: Erlangga.

Taswan. (2010). Manajemen Perbankan Konsep,Teknik, dan Aplikasi. Yogyakarta: UPP STIM YKPN

Undang-Undang No.10/1998 Tentang Perbankan Syariah Pasal 5.

Undang-Undang No.21/2008 Tentang Perbankan Syariah Pasal 1 No. 15 poin a

Wahyuni, Tri Endang. (2016). Pengaruh Faktor Syariah, Tingkat Keuntungan Bagi Hasil dan Motivasi Terhadap Keputusan Nasabah Menggunakan Perbankan Syariah. Yogyakarta: Universitas PGRI Yogyakarta.

Wulandari, Septi. (2013). Analisis Faktor Internal dan Eksternal yang Mempengaruhi Total Dana Pihak Ketiga Bank Umum Syariah di Indonesia (Studi Kasus pada Bank Umum Syariah). Skripsi. Fakultas Ekonomi, Universitas Brawijaya Malang. 